Original Article

\title{
ALTERNATIVE METHOD FOR MEASURING BEESWAX CONTENT IN PROPOLIS FROM THE NETHERLANDS
}

\author{
Elbert A. Hogendoorn ${ }^{1 *}$ \\ Marinus J. Sommeijer ${ }^{2}$ \\ Marjo J. Vredenbregt ${ }^{3}$ \\ 'Dutch Beekeepers Association Utrecht, Liesgrassingel 13, 3451 PT, \\ Utrecht, the Netherlands \\ 2Utrecht University, P.0. Box 80086, 3508 TB, Utrecht, the Netherlands \\ ${ }^{3}$ National Institute of Public Health and the Environment (RIVM), \\ P.O. Box 1, 3720 BA, Bilthoven, the Netherlands \\ *corresponding author: ehogen89@gmail.com \\ Received 19 November 2012; accepted 10 July 2013
}

\section{A bstract}

A convenient method has been developed for the separation and determination of beeswax in propolis from beehives located in the Netherlands. The method is based on differences in specific density and involves the adding of water and microwave heating of a propolis sample. After cooling to room temperature, the resulting three phase system provides a full separation of the beeswax from the propolis in the upper layer. This layer can easily be collected to quantify the authentic beeswax content of the raw propolis sample. Confirmation of the identity of beeswax isolated from propolis with this procedure, was obtained using Near Infrared Spectroscopy (NIR).

Propolis samples from 27 Dutch apiaries from various locations were analyzed using this method. The beeswax content varied between 1.0 and $42.5 \%$ with an average of $11.1 \%$. This method may also serve for the de-waxing of raw propolis prior to the isolation of biologically active compounds to be used in medicinal products.

Keywords: separation of beeswax from propolis, Near Infrared Spectroscopy, Netherlands, propolis.

\section{INTRODUCTION}

Propolis or bee glue is a resinous material that can be harvested from beehives. Honey bees (Apis mellifera) collect resin from plant sources; mainly leaf buds and bark exudates of trees. During collection and processing in the beehive, the resin material is masticated as salivary secretions are added. Other products of bee metabolism and pollen residues may be added. For the application of this resinous material in the beehive, this material is generally mixed with beeswax. The final product, called propolis, is a multi-functional product which the bees use for strengthening, cementing, waterproofing and disinfecting the hive (Burdock, 1998). Propolis plays an essential role in bee health, contributing significantly to the bees' social immunity (Simone et al., 2009; Simone and Spivak, 2010). Propolis has a long history in ancient folk medicine because it also shows activity againsthuman pathogens. The therapeutic properties of propolis have been extensively reviewed (Ghisalberti, 1979; Marcucci, 1995; Banskota et al., 2001; Almeida and Menezes, 2002; Lofty, 2006; Ramos and Miranda, 2007; Sforcin, 2007; Libério et al., 2009; Fokt et al., 2010; Bognadov, 2011; Araujo et al., 2012).

Chemically, propolis is a complex substance as it consists of numerous small and large molecular components (Ghisalberti, 1979; Markham et al., 1996; Burdock, 1998; Bankova et al., 2000; Bankova et al., 2002; Bankova, 2009). It is generally stated, that propolis is composed of around $50 \%$ resins, 30\% waxes, $10 \%$ essential oils, $5 \%$ pollen, and $5 \%$ various 
other compounds, e.g. solid debris materials from pollen grain walls and plant fibers (Ghisalberthi, 1979; Burduck, 1998). Due to variable parameters such as location of the hive, type of vegetation, seasonal time of collection, and differences between Apis mellifera (sub-) species, the composition of propolis is highly variable (Bankova et al., 1998; Salatino et al., 2005).

As indicated by scientific data, the content of wax in propolis is highly variable too, with reported values from 5 to 50\% (Farré et al., 2004; Sforcin, 2007; Lozina et al., 2010; Aliboni et al., 2011; Bonvehi and Gutiérrez, 2011). The wax component of propolis is claimed to largely consist of beeswax. The percentage of wax in propolis depends on what the bees use it for. For example, propolis used for the filling up of cracks and holes in the hive has a high wax content (Nakamura and Seeley, 2006).

Beekeepers may collect propolis from places in beehives were it is usually found in high quantities, e.g. at the ears of the frames. For the professional and standardized collection of propolis, special nets or screens are commercially available. These nets have a mesh width of $2 \mathrm{~mm}$ and are usually placed on top of the frames in the upper part of the beehive.

For therapeutic use, the biological active ingredients, viz., flavonoids, aromatic esters, and acids are, because of their polarity, extracted from the propolis with a polar organic solvent, usually ethanol or an ethanol/water mixture (Ghisalberti, 1979; Marcucci, 1995; Banskota et al., 2001; Almeida and Menezes, 2002; Lofty, 2006; Ramos and Miranda, 2007; Sforcin, 2007; Libério et al., 2009; Fokt et al., 2010; Bogdanov, 2011; Araujo et al., 2012; Extracts NZ Ltd., 2012). However, the presence of substantial amounts of non-polar beeswax can easily lead to the formation of undesirable emulsions. This is an important limitation as it may hinder the isolation of these compounds from propolis by means of ethanol. Hence, an efficient de-waxing step to facilitate the extraction appears mandatory.

Wax extraction in combination with a confirmation of the identity of the beeswax has been carried out by Negri et al. (1998; 2000). In these studies, the propolis samples were treated with ethanol in Soxhlet extractors. After cooling, the whitish wax material was isolated and further analyzed by gas chromatography/electro impact mass spectrometry. A large similarity was found in the composition of the extracted propoliswax and comb-wax, suggesting a common origin for both wax sources.

The authenticity of beeswax can also be determined by using physical-chemical parameters, such as melting point, density, acid value, saponification value, ration number, ester value, iodine absorption number, and peroxide value (Bogdanov, 2004; Bernal et al., 2005). When using sufficient parameters, adulteration percentages down to $5 \%$ can be determined.

Both the de-waxing and analytical procedures to confirm the identity of the isolated beeswax are laborious and demand advanced technology (Negri et al., 1998; Negri et al., 2000; Jiménez et al., 2003; Jiménez et al., 2004; Bernal et al., 2005; Jiménez et al., 2007; Bonvehi and Bernejo, 2012).

The aim of our study is two-fold. First we developed a basic and efficient procedure for the determination of beeswax in propolis. Second, we applied our method for an inventory of the quantitative occurrence of beeswax in propolis from apiaries of beekeepers in the Netherlands.

\section{MATERIAL AND METHODS}

\section{Earlier pooled samples for preliminary analysis}

Prior to the main study (in 2008, 2009, 2010), we collected propolis over some time, at four apiaries. The collected amounts were pooled per apiary. The obtained samples of $100 \mathrm{~g}(\mathrm{n}=2)$, $180 \mathrm{~g}$, and $200 \mathrm{~g}$ were analyzed, respectively, in total, for wax content. The samples were heated "au-bain-marie" (water temperature kept at about $90^{\circ} \mathrm{C}$ ) until the whole sample had become liquid. By slowly cooling the samples to room temperature, the beeswax separated from the dark brown propolis as a top layer of relatively uniform thickness.

\section{Collection of individual samples}

Raw propolis samples were obtained from bee colonies of Dutch beekeepers. The samples 


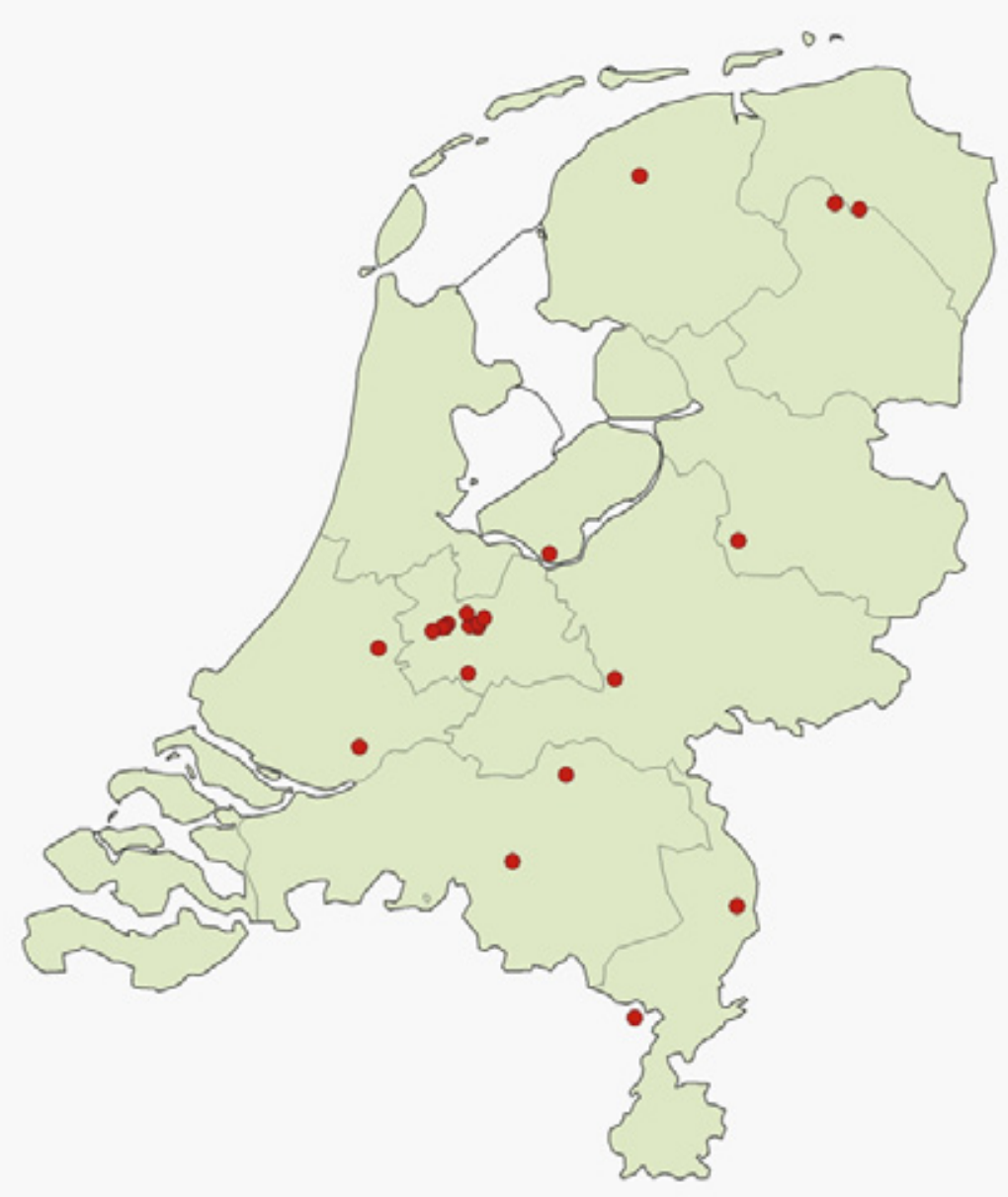

Fig. 1. Apiary locations in the Netherlands from where propolis samples were taken.

were collected by scraping propolis from the ears of the wooden frames and other depositions inside the hive, such as queen excluders and hive-covers.

These 28 samples consisted of two series. The first series was collected from apiaries in the province of Utrecht and the second series was collected from all over the country. Figure 1 shows the locations of the apiaries from which the 28 propolis samples were taken. One sample was collected in Belgium just across the border of Southeast Netherlands. The samples were taken in 2010 and 2011. The weight of these samples ranged between 5 to $50 \mathrm{~g}$. For the validation of the method, a duplicate sample was analyzed for each collected amount above $40 \mathrm{~g}$ (15 samples, see Tab. 2).

As reference material for confirmation purposes, we used pure beeswax obtained from comb cappings of the honey harvested in 2009,2010, and 2011 (apiary Vleuten, 3451 PT).

\section{Preparation of the samples}

The individual propolis samples $(n=28)$ were manually chopped at an ambient temperature (ca. $15-20^{\circ} \mathrm{C}$ ) in pieces of about $1-2 \mathrm{~g}$ and mixed; $20.00 \mathrm{~g}$ of each sample were transferred into a $50 \mathrm{~mL}$ polypropylene tube which had a screw cap. Samples consisting of smaller amounts of propolis, were transferred, in total, to the tube (minimally $5 \mathrm{~g}$ ).

At a temperature of about minus $4^{\circ} \mathrm{C}$, a subset of four samples was firstly ground to powder in a coffee grinder machine. Next, a $50 \mathrm{~mL}$ tube which had a screw cap was used to hold $15 \mathrm{~g}$ of the powder.

\section{Separation of beeswax and determination of content}

The amount of $25 \mathrm{~mL}$ of de-ionized water was added to the $20 \mathrm{~g}$ of chopped propolis. When adding the water to the powdered sample, it is necessary to constantly and carefully stir 
the mixture to avoid propolis powder floating on the water surface. After loosely tightening the screw cap to prevent pressure building up while heating, the tubes were vertically placed in a household microwave apparatus which was set at medium. The time of heating was adjusted so that the temperature rises to about $100^{\circ} \mathrm{C}$ but without the boiling of the water phase. Depending on the number of samples and their size, the heating time ranged between 1 and 4 minutes. Next, cooling down the samples to room temperature provided a three layer system in the tubes: the beeswax (upper layer), then water (middle layer), and de-waxed propolis at the bottom. With a small stainless steel spatula the beeswax in the upper layer was transferred to a paper tissue for the removal of the remaining water. Next, the amount of extracted beeswax was weighed and the content as a percentage of the weight was calculated.

Instrumental analysis (NIR) of the beeswax in the propolis samples

About $200 \mathrm{mg}$ of the separated wax were put into the bottom of a glass vial. Next, the vial was shortly heated to melting temperature (about $60^{\circ} \mathrm{C}$ ) so that the sample could be put into a vial for the NIR analysis. NIR spectra were recorded on an Antaris II FT-NIR spectrometer (Thermo Scientific, Madison, USA) equipped with an integrating sphere and an InGaAs detector. Measurements were carried out in the diffuse reflection mode with an optical resolution of $8 \mathrm{~cm}^{-1}$ over the spectral range of $10000-4000 \mathrm{~cm}^{-1}$, and 32 spectra were co-added. All samples were measured twice. Spectra were compared using Omnic software (version 7.3).

\section{Statistical analysis}

A statistical analysis of the duplicate samples calculates the variation of the beeswax content expressed as the relative standard deviation $\left(R_{\mathrm{i}}\right)$ for sample $\mathrm{i}$.

$R S D_{i}=\frac{\sqrt{\sum\left(x_{i j}-\overline{x_{i}}\right)^{2}}}{\overline{x_{i}}}$ With $x_{i i j}$ the $j^{\text {th }}$ result for sample $i$ and

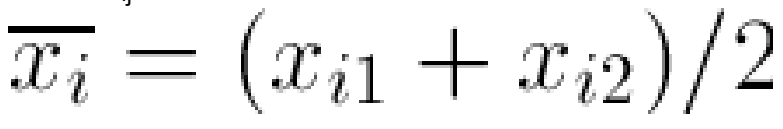

The overall relative standard deviation is calculated by pooling as:

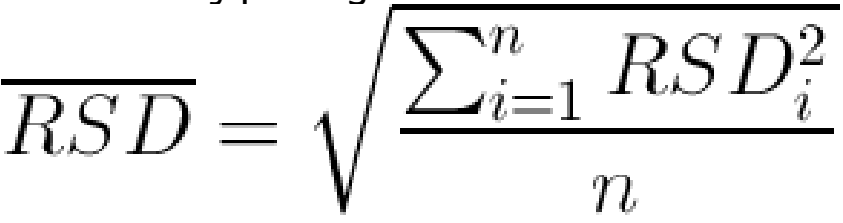

(Gort and Hoogerbrugge, 1995).

\section{RESULTS}

\section{Preliminary experiments}

In the preliminary experiments with pooled apiary samples, the separation was carried out by heating "au-bain-marie" and without adding water to the samples. By separating the top layer above the propolis stratum and subsequently weighing this wax fraction, the beeswax content of these samples could be determined and the results are shown in Table 1.

The beeswax content of these samples ranged between 5 and $12.5 \%$ (Tab. 1). Over a two year period, at the apiary of Vleuten (3451PT) the yearly harvest of raw propolis per hive $(n=7)$ was about $60 \mathrm{~g}$.

Beeswax content $(\%, w / w)$ in pooled propolis season samples

Table 1.

\begin{tabular}{cccc}
\hline $\begin{array}{c}\text { City and Postal code* } \\
\text { of apiary }\end{array}$ & $\begin{array}{c}\text { Season of } \\
\text { collection }\end{array}$ & $\begin{array}{c}\text { Amount } \\
\text { analyzed } \\
\text { (g) }\end{array}$ & $\begin{array}{c}\text { Beeswax } \\
\text { content } \\
\text { (\%) }\end{array}$ \\
\hline Utrecht, 3584 AD & $2008 / 2009$ & 100 & 6.5 \\
\hline Vleuten, 3451 PT & $2008 / 2009$ & 100 & 8.0 \\
\hline Vleuten, 3451 PT & $2009 / 2010$ & 200 & 12.5 \\
\hline Zeewolde, 3896LA & $2009 / 2010$ & 180 & 5.0 \\
\hline
\end{tabular}

*In the Netherlands (NL)

04 
Table 2.

Beeswax content $(\%, w / w)$ in propolis samples of various locations $(n=28)$

\begin{tabular}{|c|c|c|c|}
\hline $\begin{array}{l}\text { Apiary (City, Postal code, } \\
\text { Netherlands/Belgium) }\end{array}$ & Subsample 1 & Subsample 2 & Average \\
\hline \multicolumn{4}{|c|}{ Duplicate samples } \\
\hline Deventer, 8121 PR, NL & 42.5 & 49.5 & 46.0 \\
\hline Dordrecht, $3314 \mathrm{BH}, \mathrm{NL}$ & 5.0 & 5.0 & 5.0 \\
\hline Eelde, $9761 \mathrm{BE}, \mathrm{NL}$ & 6.5 & 5.3 & 5.9 \\
\hline Geffen, 5386 KR, NL & 15.5 & 13.0 & 14.3 \\
\hline Grubbenvorst, 5971 VX, NL & 30.5 & 27.5 & 29.0 \\
\hline Kinrooy, 3640, Belgium & 27.0 & 28.5 & 27.8 \\
\hline Maarsseveen, 3566 JS, NL & 4.6 & 2.6 & 3.6 \\
\hline Reeuwijk, $2811 \mathrm{GN}, \mathrm{NL}$ & 2.0 & 6.0 & 4.0 \\
\hline Vleuten, $3451 \mathrm{PT}, \mathrm{NL}$ & 5.5 & 6.5 & 6.0 \\
\hline Vleuten, $3451 \mathrm{RD}, \mathrm{NL}$ & 7.0 & 6.4 & 6.7 \\
\hline Zeewolde, 3896 LA, NL & 7.8 & 5.0 & 6.4 \\
\hline Apeldoorn, $7325 \mathrm{AK} \mathrm{NL}^{*}$ & 4.5 & 4.1 & 4.3 \\
\hline De Meern, 3454 HE, NL* & 1.0 & 1.0 & 1.0 \\
\hline Opheusden, $6701 \mathrm{PZ}, \mathrm{NL}^{*}$ & 21.8 & 20.6 & 21.2 \\
\hline Utrecht, $3571 \mathrm{KL}, \mathrm{NL}^{*}$ & 2.8 & 3.0 & 2.9 \\
\hline \multicolumn{4}{|c|}{ Single samples } \\
\hline Groenekan, 3737 RA, NL & 2.0 & & \\
\hline Harmelen, 3481LH, NL & 4.6 & & \\
\hline Leeuwarden, 8916 GN, NL & 7.5 & & \\
\hline Noordlaren, 9479 PB, NL & 10.0 & & \\
\hline Oirschot, 5688 JX, NL & 18.5 & & \\
\hline Udenhout, 5071 BJ, NL & 5.3 & & \\
\hline Utrecht, $3561 \mathrm{PK}, \mathrm{NL}$ & 5.9 & & \\
\hline Utrecht, 3552 CP, NL & 11.0 & & \\
\hline Utrecht, 3514 XR, NL & 12.5 & & \\
\hline Utrecht, 3584 AD, NL & 6.5 & & \\
\hline Vianen, 4132 XE, NL & 20.0 & & \\
\hline Vleuten, $3451 \mathrm{PP}, \mathrm{NL}$ & 11.6 & & \\
\hline Wageningen, 6707 BN, NL & 12.0 & & \\
\hline Average of all samples & 11.1 & 12.3 & 12.3 \\
\hline
\end{tabular}

*Sample ground to powder at a low temperature prior to analysis. 
Table 3.

Overview of method performance

\begin{tabular}{ccc}
\hline $\begin{array}{c}\text { Type of sample } \\
\text { preparation }\end{array}$ & $\begin{array}{c}\text { Number of } \\
\text { duplicates }\end{array}$ & $\begin{array}{c}\text { Overall relative } \\
\text { standard deviation }\end{array}$ \\
\hline $\begin{array}{c}\text { Manual cutting and mixing } \\
\text { at room temperature }\end{array}$ & 11 & $27 \%$ \\
\hline $\begin{array}{c}\text { Grinding at } \\
\text { a low temperature }\end{array}$ & 4 & $4.5 \%$ \\
\hline
\end{tabular}

\section{The individual samples}

The samples collected for the inventory of a larger area, contained considerably less material each. This required a modification of the procedure applied for the pooled samples. For reasons of efficiency, the possibility of using a microwave oven for heating was investigated, in combination with a standardized sample size of $20 \mathrm{~g}$.

During our first trials with the simultaneous microwave heating of 4 - 8 samples, an unexpected large difference in temperature increase was observed between individual samples. Even when reducing the heating time to less than 1 min, some samples started boiling. The result was that sample material attached to the underside of the screw cap. After this, microwave heating was combined with the addition of a volume of water to the sample, to smoothen the extraction power. This was successful, and we found that a satisfactory separation was obtained by microwave heating of a sample in a $50 \mathrm{~mL}$ tube that consisted of $20 \mathrm{~g}$ of homogenized raw propolis to which $25 \mathrm{~mL}$ of water was added.

The results are shown in Table 2. The beeswax content of the individual samples collected all over the Netherlands, ranged between 1 and $42.5 \%$. The average beeswax content in the studied population ( $n=28$ ) was $11.1 \%$. This is within the range of the pooled samples (Tab. 1). As shown in Table 3, the overall relative standard deviation for these 11 duplicate values is $27 \%$. The analysis of the four duplicate samples that were ground to powder at a low temperature resulted in a relative standard deviation of $4.5 \%$.

\section{Confirmation of beeswax}

The separation procedure provides a yellowish material that looks very similar to pure beeswax from comb cappings (see Materials).

For the unambiguous confirmation that the material of the separated top layer really consisted of beeswax, NIR spectra were recorded of a randomly selected number of beeswaxes obtained from propolis samples $(n=7)$ as well as of pure beeswax. The NIR spectra of beeswax obtained from the seven propolis samples showed a very high similarity and a large mutual agreement with spectra of the pure beeswax sample. An example is given in Figure 2, showing the NIR spectra of pure beeswax from comb cappings and the beeswax obtained from a propolis sample of the apiary Vleuten (3451PT). The similarity between the spectra unambiguously confirms the similar composition of both waxes.

\section{DISCUSSION}

The difference in density between propolis and beeswax can advantageously be used for the separation of these two materials by heating and cooling the raw propolis, with or without the presence of water. The use of water provides a three-layer system consisting of propolis (at the bottom), water (middle layer), and beeswax (floating on top), and, hence, a complete physical separation of the two materials. Microwave heating accelerates the method, rendering a fast, simple and low cost procedure, suitable for small samples.

To confirm that the separated wax from propolis corresponds to pure beeswax, we used NIR technology. This fast and nondestructive technique for comparison or verification of the identity of chemicals is widely used in food and 


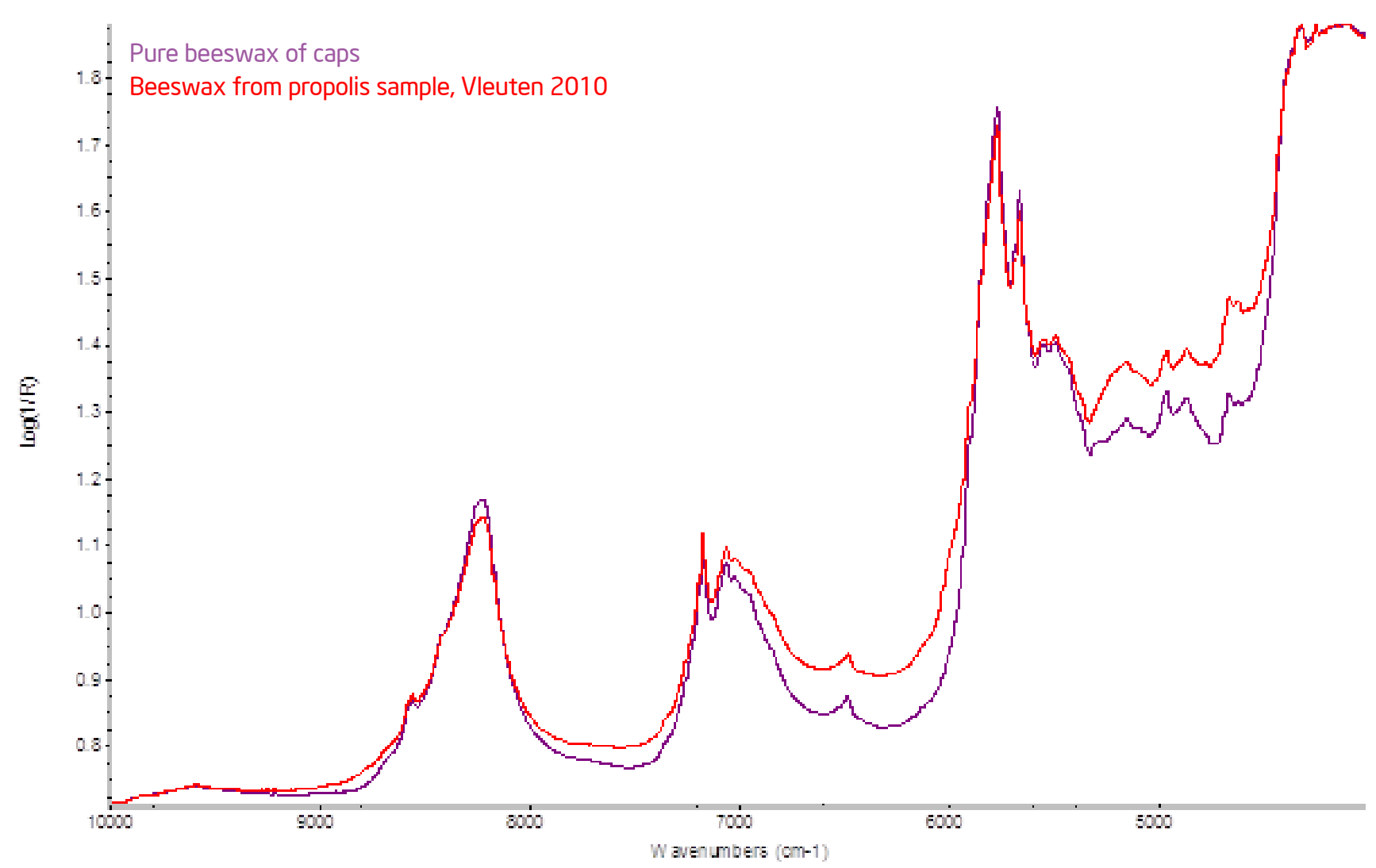

Fig. 2. NIR spectra of beeswax obtained from a propolis sample of apiary Vleuten 3451PT and of pure beeswax obtained from comb caps, both from 2010.

pharmaceutical analysis (Blanco et al., 1998; Qiu et al., 1999; Nicolaï et al., 2007). The NIR-results clearly confirmed that the separated solid phase from the raw propolis is beeswax. This proves that our simple separation procedure is in agreement with the sophisticated instrumental analysis of beeswax samples extracted from propolis samples (Negri et al., 1998; Negri et al., 2000; Lozina et al., 2010; Bonvehi and Gutiérrez, 2011).

The variation of the beeswax content in the samples $(1-42.5 \%)$ corresponds with the ranges found in literature of 2 - 30\% (Aliboni et al., 2011), 7.5 - 35\% (Farré et al., 2004), 2 - 30\% (Bonvehi and Gutiérrez, 2011) and 3.8 - 30.6\% (Lozina et al., 2010). As mentioned above, the chemical composition of propolis is highly variable due to various reasons - the variation in vegetal origin and location being the most important ones. However, in this inventory the high range in beeswax content is most likely the result of the non-standardized sampling carried out by the individual beekeepers. Propolis collected from different locations in the hive may have different beeswax contents.
The overall performance of the method is given in Table 3. The found standard deviation of $27 \%$ for the 11 duplicate samples reflects the difficulty encountered in homogenizing the sample. At room temperature, the raw propolis is very sticky which hampers manual chopping and mixing. Consequently, the variation for the duplicate values is mainly due to sample inhomogeneity. The results obtained for the duplicate samples ground at a low temperature have a relative standard deviation of $4.5 \%$. However, since this analysis is distinctly more laborious and requires specific laboratory facilities (cold room and special equipment), we recommend as a simple analysis methodology, the use of the manual chopping and mixing of collected raw propolis at an ambient temperature.

Our method provides a satisfactory separation of the beeswax from propolis. On one hand, this separation might facilitate the further processing of propolis for therapeutic use. On the other hand, the odorous beeswax separated in this way might render a very attractive product for use in pharmacopoeia and cosmetics (Tihonov et al., 1986). 
At the same time, the water phase of the threelayer separation procedure might be of interest in extracting polar biological active compounds rendering an aqueous solution for possible therapeutic application. We cannot exclude that the valuable properties of propolis might change due to the heating process of the method. We experienced that heating the propolis, as applied here for the segregation of beeswax, significantly enhances the lifetime of propolis. Propolis heated for de-waxing and kept under proper conditions did not change in texture and sensory characteristics even after more than 20 years. Without such a preheating step, pulverization of propolis was sometimes observed to start after several months, probably caused by microbial action.

\section{CONCLUSIONS}

A simple and efficient method has been developed for the separation of beeswax in raw propolis collected from beehives. With the developed procedure, an inventory of beeswax content in propolis samples from beehives of Dutch apiaries was carried out showing an average beeswax content of $11 \%$ with a range between 1.0 and $42 \%$.

\section{ACKNOWLEDGMENTS}

The advice and supporting information from Arie den Boer and Ronald Hoogerbrugge are greatly acknowledged.

\section{REFERENCES}

Aliboni A., D’Andrea A., Massanisso P. (2011) Propolis specimens from different locations at central Italy: Chemical profiling and gas chromatography-mass spectrometry (GC-MS) quantitative analysis of the allergenic esters benzyl cinnamate and benzyl salicylate. Journal of Agricultural and Food Chemistry 59: 282-288. DOl: 10.1021/jf1034866

Almeida E. C. de, Menezes H. (2002) Anti-inflammatory activity of propolis extracts: A review. Journal of Venomous Animals and Toxins 8(2): DOl: 10.1590/S010479302002000200002
Araujo M. A. R., Libério S. A., Guerra R. N. M., Ribeiro G. M. N. S., Nascimento F. R. F. (2012) Mechanisms of action underlying the anti-inflammatory and immunomodulatory effects of propolis: a brief review. Revista Brasileira de Farmacognosia/Brazilian Journal of Pharmacognosy 22(1): 208-219. DOl: 10.1590/S0102$695 \times 20110005000167$

Bankova V. (2009) Chemical diversity of proprolis makes it valuable source of new biologically active compounds. Journal of ApiProduct and ApiMedical Science 1 (2): 23-28

Bankova V. S., Castro S. L. de, Maracucci M. C. (2000) Propolis: recent advances in chemistry and plant origin Apidologie 31: 3-15.

Bankova V., Popova M., Bogdanov S., Sabatini A. G. (2002) Chemical Composition of European Propolis: Expected and Unexpected Results. Zeitschrift für Naturforschung 57c: 530-533.

Bankova V., Boudourova-Krasteva G., Popov S., Sforcin J. M., Funari S. R. C. (1998) Seasonal variations of the chemical composition of Brazilian propolis. Apidologie 29: 361-367.

Banskota A. H., Tezuka Y., Kadota S. (2001) Recent progress in pharmacological research of propolis. Phytherapy Research 15: 561-571. DOl: 10.1002/ ptr.1029

Bernal J. L., liménez J. J., del Nozal M. J., Toribio L., Martin M. T. (2005) Physico-chemical parameters for the characterization of pure beeswax and detection of adulterations. European Journal of Lipid Science and Technology 107: 158-166. DOI 10.1002/ ejlt.200401 105

Blanco M., Coello J., Iturriage H., Maspoch S., de la Pezuela C. (1998) Critical Review: Near-Infrared spectroscopy in the pharmaceutical industry. Analyst 123: 135R-150R 
Bogdanov S. (2004) Beeswax: quality issues today. Bee World 85: 46-50.

Bogdanov S. (2011) Propolis: Composition, Health Medicine: A review. Bee Product Science. 33 pp. Available at: http://www.apitherapie.ch/files/files/ Pollen/PollenBook2Review.pdf

Bonvehi J. S., Bernejo F. J. O. (2012) Detection of adulterated commercial Spanish beeswax. Food Chemistry 132: 642-648. DOl: 10.1016/j.foodchem.2011.10.104

Bonvehi J. S., Gutiérrez A. L. (201 1) The antimicrobial effects of propolis collected in different regions in the Basque Country (Nothern Spain). World Journal of Microbiology and Biotechnology DOl: 10.1007/ s1 1274-011-0932-y

Burdock G. A. (1998) Review of the biological properties and toxicity of bee propolis (propolis). Food and Chemical Toxicology 36: 347-363.

Extracts NZ Ltd. (2012) http://www.techlink.org. nz/Case-studies/Technological-practice/Food-andBiological/propolis/index.htm

Farré R., Frasquet I., Sanchez A. (2004) Propolis and human health. Ars Pharmaceutica 45: 21 -43.

Fokt H., Pereira A., Ferreira A. M., Cunha A., Aguiar C. (2010) How do bees prevent hive infections? The antimicrobial properties of propolis. In: Méndez-Vilas A. (Ed.) Current Research, Technology and Education Topics in Applied Microbiology and Microbial Biotechnology. Formatex. Badajoz. pp. 481 -493.

Ghisalberti E. L. (1979) - Propolis: A review. Bee World 60: 59-84.

Gort S. M., Hoogerbrugge R. (1995) A user-friendly spreadsheet program for calibration using weighted regression. Chemometrics and Intelligent Laboratory Systems 28: 193-199.

Jiménez J. J., Bernal J. L., Aumente S., Toribio L., Bernal J. Jr. (2003) Quality assurance of commercial beeswax II. Gas chromatography-electron impact ionization mass spectrometry of alcohols and acids. Journal of
Chromatography A 1007: 101-116. DOl: 10.1016 / S0021-9673(03)00962-2

Jiménez J. J., Bernal J. L., del Nozal M. J., Toribio L." Bernal J. (2007) - Detection of beeswax adulterations using concentration guide-values. European Journal of Lipid Science and Technology 109: 682690. DOl 10.1002/ejlt.200600308

jiménez J. J., Bernal J. L., Aumente S., del Nozal M. J., Martin T., Bernal J. Jr. (2004) Quality assurance of commercial beeswax I. Gas chromatographyelectron impact ionization mass spectrometry of hydrocarbons and monoesters. Journal of Chromatography A 1024: 147-154. DOl: 10.1016/j.chroma.2003.10.063

Libério S. A., Pereira A. L., Araújo M. J. A. M., Dutra R. P., Nascimento F. R. F., Monteiro-Neto V., Ribeiro M. N. S., Goncalves A. G., Guerra R. N. M. (2009) The potential use of propolis as a cariostatic agent and its actions on mutans group streptococci. Journal of Ethnopharmacology 125: 1-9. DOl: 10.1016/j. jep.2009.04.047

Lofty M. (2006) Biological activity of bee propolis in health and disease. Asian Pacific Journal of Cancer Prevention 7: 22-31.

Lozina L. A., Peichoto M., Acosta O. C., Granero G. E. (2010) Estandarización y caractterización organoléptica y físico-química de 15 propóleos de Argentinos. Latin American Journal of Pharmacy 29: 102 110.

Marcucci M. C. (1995) Propolis: Chemical composition, biological properties and therapeutic activity. Apidologie 26: 83-89.

Markham K. R., Mitchell K. A., Wilkins A. L., Daldy J. A., Lu Y. (1 996) HPLC and GC-MS identification of the major organic constituents in New Zealand propolis. Phytochemistry 42: 205-211.

Nakamura J., Seeley T. D. (2006) The functional organization of resin work in honeybee colonies. Behavioral Ecology and Sociobiology 60: 339-349. DOl: 10.1007/s00265-006-0170-8 
Negri G., Marcucci M. C., Salatino A., Salatino M. L. F. (1998) Hydrocarbons and monoesters of propolis waxes from Brazil. Apidologie 29: 305-314.

Negri G., Marcucci M. C., Salatino A., Salatino M. L. F. (2000) Comb and propolis waxes from Brazil (states of Sao Paulo and Paraná). Journal of the Brazilian Chemical Society 1 1: 1-8.

Nicolaï B. M., Beullens K., Bobbely E., Peirs A., Saeys W., Theron K. I., Lammertyn J. (2007) Nondestructive measurement of fruit and vegetable quality by means of NIR spectroscopy: A review. Postharvest Biology and Technology 46: 99-118. DOl: 10.1016/j.postharvbio.2007.06.024

Qiu P. Y., Ding H. B., Tang Y. K., Xu R. J. (1999) Determination of chemical composition of commercial honey by Near-Infrared spectroscopy. Journal of Agricultural and Food Chemistry 47: 2760-2765.

Ramos A. F. N., Miranda J. L. (2007) Propolis: A review of its anti-inflammatory and healing actions. Journal of Venomous Animals and Toxins including Tropical Diseases 13: 697-710.
Salatino A., Teixeira E. W., Negri G., Message D. (2005) Origin and chemical variation of Brazilian propolis. eCAM 2: 33-38. DOl: 10.1093/ecam/neh060

Sforcin J. M. (2007) Propolis and the immune system: a review. Journal of Ethnopharmacology 113: 1-14. DOl: 10.1016/j.jep.2007.05.012

Simone M., Evans J. D., Spivak M. (2009) Resin collection and social immunity in honey bees. EvoIution 63: 3016-3022. DOl: 10.1111/j.15585646.2009.00772.x

Simone-Finstrom M., Spivak M. (2010) Propolis and bee health: the natural history and significance of resin use by honey bees. Apidologie 41:295-2010. DOl: 10.1051/apido/2010016

Tihonov A. I., lavtushenko S. V., Achilov I., larnih T. C. (1986) Some facts about beeswax extracted from propolis. Apiacta 1: 1-2. 